Nat. Hazards Earth Syst. Sci., 19, 873-888, 2019

https://doi.org/10.5194/nhess-19-873-2019

(C) Author(s) 2019. This work is distributed under the Creative Commons Attribution 4.0 License.

\title{
Damage induced by the 25 April 2015 Nepal earthquake in the Tibetan border region of China and increased post-seismic hazards
}

\author{
Zhonghai $\mathrm{Wu}^{1}$, Patrick J. Barosh ${ }^{2, a}$, Guanghao $\mathrm{Ha}^{1}$, Xin Yao ${ }^{1}$, Yongqiang $\mathrm{Xu}^{3}$, and Jie Liu \\ ${ }^{1}$ Institute of Geomechanics, Chinese Academy of Geological Sciences, Beijing 100081, China \\ ${ }^{2}$ P.J. Barosh and Associates, 103 Aaron Avenue, Bristol, RI 02809, USA \\ ${ }^{3}$ China Institute of Geo-environment Monitoring, Beijing 100081, China \\ ${ }^{4}$ National Administration of Surveying, Mapping and Geoinformation, Beijing 100830, China \\ ${ }^{\mathrm{a}}$ visiting scientist at: Chinese Academy of Geological Sciences, Beijing 100081, China
}

Correspondence: Zhonghai Wu (wuzhonghai@geomech.ac.cn)

Received: 2 July 2018 - Discussion started: 27 July 2018

Revised: 8 March 2019 - Accepted: 16 March 2019 - Published: 18 April 2019

\begin{abstract}
The seismic effects in Nyalam, Gyirong, Tingri and Dinggye counties along the southern border of Tibet were investigated during 2-8 May 2015, a week after the great Nepal earthquake along the Main Himalaya Thrust. The intensity was VIII in the region and reached IX at two towns on the Nepal border, resulting in the destruction of 2700 buildings, seriously damaging over 40000 others, while killing 27 people and injuring 856 in this sparsely populated region. The main geologic effects in this steep rugged region are collapses, landslides, rockfalls, and ground fissures, many of which are reactivations of older land slips. These did great damage to the buildings, roads, and bridges in the region. Most of the effects are along four incised valleys which are controlled by $\mathrm{N}$-trending rifts and contain rivers that pass through the Himalaya Mountains and flow into Nepal; at least two of the larger aftershocks occurred along the normal faults. And, the damage is not related to the faulting of $\mathrm{N}$ trending rifts but rather is distributed along the intensity of Nepal earthquake. Areas weakened by the earthquake pose post-seismic hazards. Another main characteristic of damage is the recurrence of the old landslide and rockfalls. In addition, there is an increased seismic hazard along active $\mathrm{N}$ trending grabens in southern Tibet due to the shift in stress resulting from the thrust movement that caused the Nepal earthquake. NW-trending right-lateral strike-slip faults also may be susceptible to movement. The results of the findings are incorporated in some principle recommendations for the repair and reconstruction after the earthquake.
\end{abstract}

\section{Introduction}

On 25 April 2015 at 14:11:26 MGT+8 (Beijing time), a great $M_{\mathrm{S}} 8.1\left(M_{\mathrm{w}} 7.8\right)$ earthquake struck Nepal and adjacent regions, killing more than 8800 people and injuring more than 23 000. The epicenter was near Pokhara, $77 \mathrm{~km}$ northwest of the capital of Kathmandu, and the hypocenter was at a depth of $10-24 \mathrm{~km}$. Many aftershocks of magnitude $4.5 M_{\mathrm{w}}$ or greater followed, of which a $M_{\mathrm{S}} 7.5\left(M_{\mathrm{w}} 7.3\right)$ aftershock occurred after 17 days on 12 May 2015 at 15:05. This epicenter was near the Chinese border $77 \mathrm{~km}$ east-northeast of Kathmandu, and the hypocenter was at a depth of $12-16 \mathrm{~km}$.

The main earthquake occurred on the south slope of the Himalaya Mountains and formed a 120-140 km long and about $80 \mathrm{~km}$ wide rupture zone with a dip slip of $3.5-5.5 \mathrm{~m}$, which shows an expansion from west to east (USGS, 2015a, b; IRIS, 2015). The aftershock distribution, the focal mechanism solution, and the source rupture inversion suggest that the earthquake was a release of built up strain along the Main Himalaya Thrust (MHT) fault zone and part of the ongoing process of the Indian Plate underthrusting the Eurasian Plate (Fig. 1). This was the strongest seismic event since the 2005 $M_{\mathrm{S}} 7.8$ Pakistan Kashmir earthquake, which also occurred along the Main Himalaya Thrust. These earthquakes may indicate that the seismic activity along the thrust is entering a new active phase.

The earthquake affected Nepal, northern India, Pakistan, Bhutan, and southern Tibet. The main damage characteristics have been reported for Nepal (Bijukchhen et al., 2017; Yun et al., 2015). However, there was a lack of damage investi- 


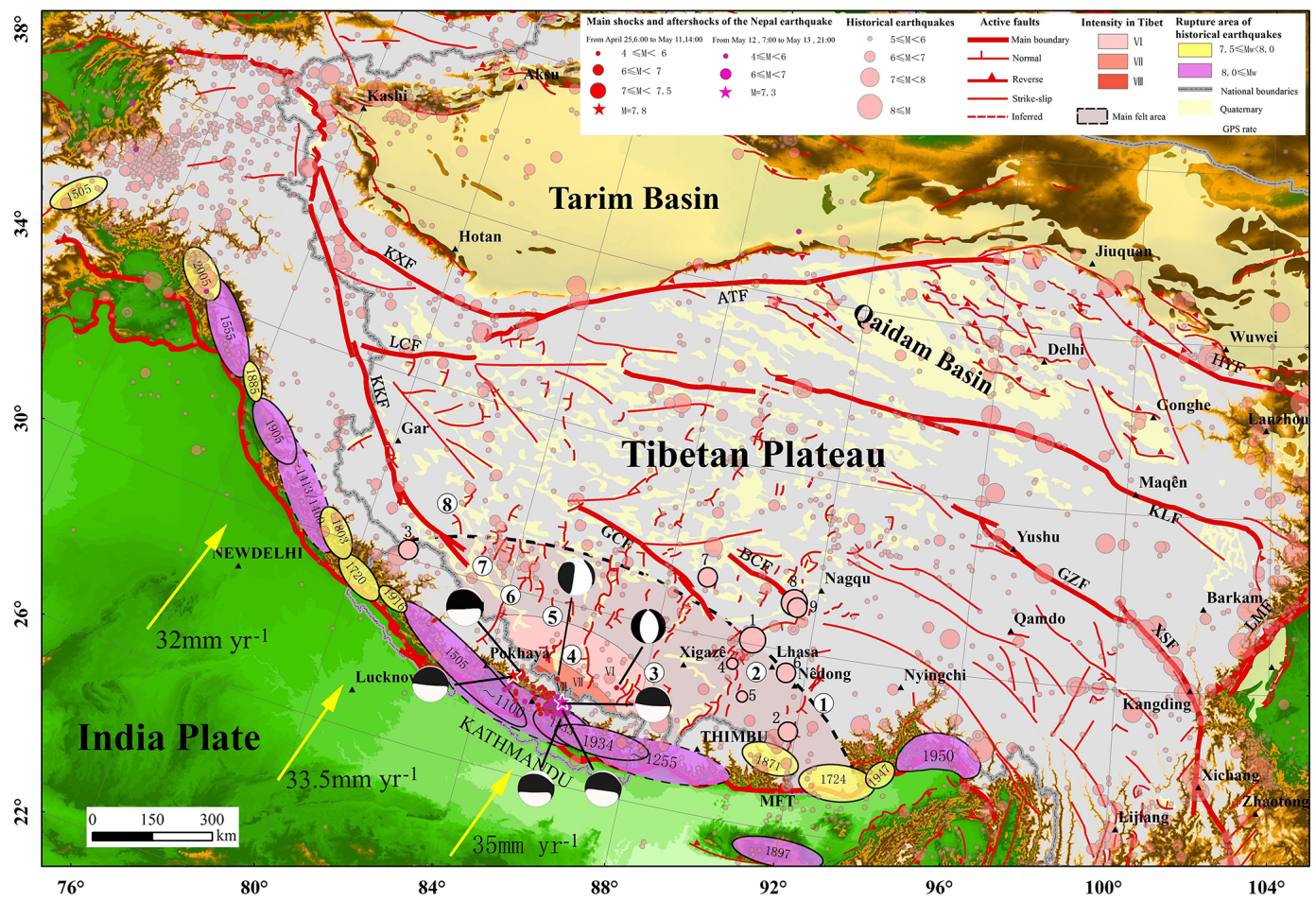

Figure 1. Principal active faults and historic earthquakes in the Himalaya Mountains, Tibetan Plateau, and neighboring areas. The earthquake data are from the Science and Technology Committee and the archives in Xizang Autonomous Region (1982), Bilham (2004), and Avouac (2007). GPS data are from Bettinelli et al. (2006). The focal mechanism solution data are from USGS (2015a, b), the Institute of Geophysics, China Earthq. Admin. (2015), and the China Earthquake Administration (2015). Circled numbers denote rifts in southern Tibet as follows: (1) Cona-Oiga rift, (2) Yadong-Gulu rift, (3) Dinggye-Xainza rift, (4) Gangga-Tangra Yumco rift, (5) Nyalam-Coqên rift, (6) Zhongba-Gêrzê rift, (7) Kunggyu Co-Yagra rift, and (8) Burang-Gêgyai rift. Thrust and strike-slip faults are denoted as follows: MFT, Main Frontal Thrust fault of Himalaya; KKF, Karakorum fault; GCF, Gyaring Co fault; BCF, Beng Co fault; GZF, Ganzi fault; XSF, Xianshuihe fault; KLF, Kunlunshan fault; LMF, Longmenshan fault; LCF, Longmu Co fault; KXF, Kangxiwa fault; AFT, Altyn Tagh fault; and HYF, Haiyuan fault. Numbers 1-9 denote the $M \geq 6.8$ historic earthquake epicentral areas in southern Tibet: $1-1411 M 8.0$ DamxungYangbajain; 2 - $1806 M$ 7.5 Cona; 3 - $1883 M 7.0$ Burang; 4 - $1901 M$ 6.8 Nyêmo; 5 - $1909 M$ 6.8 Nagarze; 6 - $1915 M 7.0$ Sangri; 7 $1934 M 7.0$ Gomang Co of Xainza; 8 - 1951 M 8.0 Beng Co of Nagqu; and 9 - $1952 M 7.5$ Gulu of Nagqu.

gation in China, which is the focus of this paper. In China the tremors were felt in Xigazê and Lhasa to the north and over an area of $300000 \mathrm{~km}^{2}$ but were strongest in the ChinaNepal border area, which is only about $40 \mathrm{~km}$ (Figs. 1, 2) from the epicenter (Table 1). Despite the great loss of life in Nepal, the disaster only caused 27 deaths, 856 injuries, and 3 missing in China, although the damage was extensive. About 300000 people were affected, and the direct economic loss was more than RMB 33000 million (USD 5.178 billion). Fortunately, the border area has a low population density, and the earthquake occurred in the afternoon when many were outside, otherwise the casualty and economic loss would have been much higher. Due to the rapid response of the local governments, displaced people were soon resettled in southern Tibet.

An emergency seismic hazard investigation group of 12 people was organized by the Ministry of Land and Resources to survey the hardest hit four counties of Nyalam, Gyirong, Tingri, and Dinggye during 2-8 May, a week af- ter the main shock, in order to quickly understand the earthquake effects and potential future threats to provide a basis for the post-earthquake reconstruction. The group then held meetings with the local governments to present their findings and recommendations. This paper is a brief summary of the direct effects observed in the field and an investigation into the delayed effects that may cause just as much damage.

\section{Seismic-geological setting}

The Tibetan Plateau is well known for its numerous E-W to NW, north-dipping thrust faults that facilitated its rise as the India Plate collided and was thrust beneath it. Most of the uplift occurred by the Miocene (Dewey et al., 1988; Wu et al., 2008) and the majority of the thrust faults came to a stop as the movement evolved and concentrated along fewer strikeslip faults, which remain very active and capable of great earthquakes (Armijo et al., 1989; Fig. 1). However, thrusting 


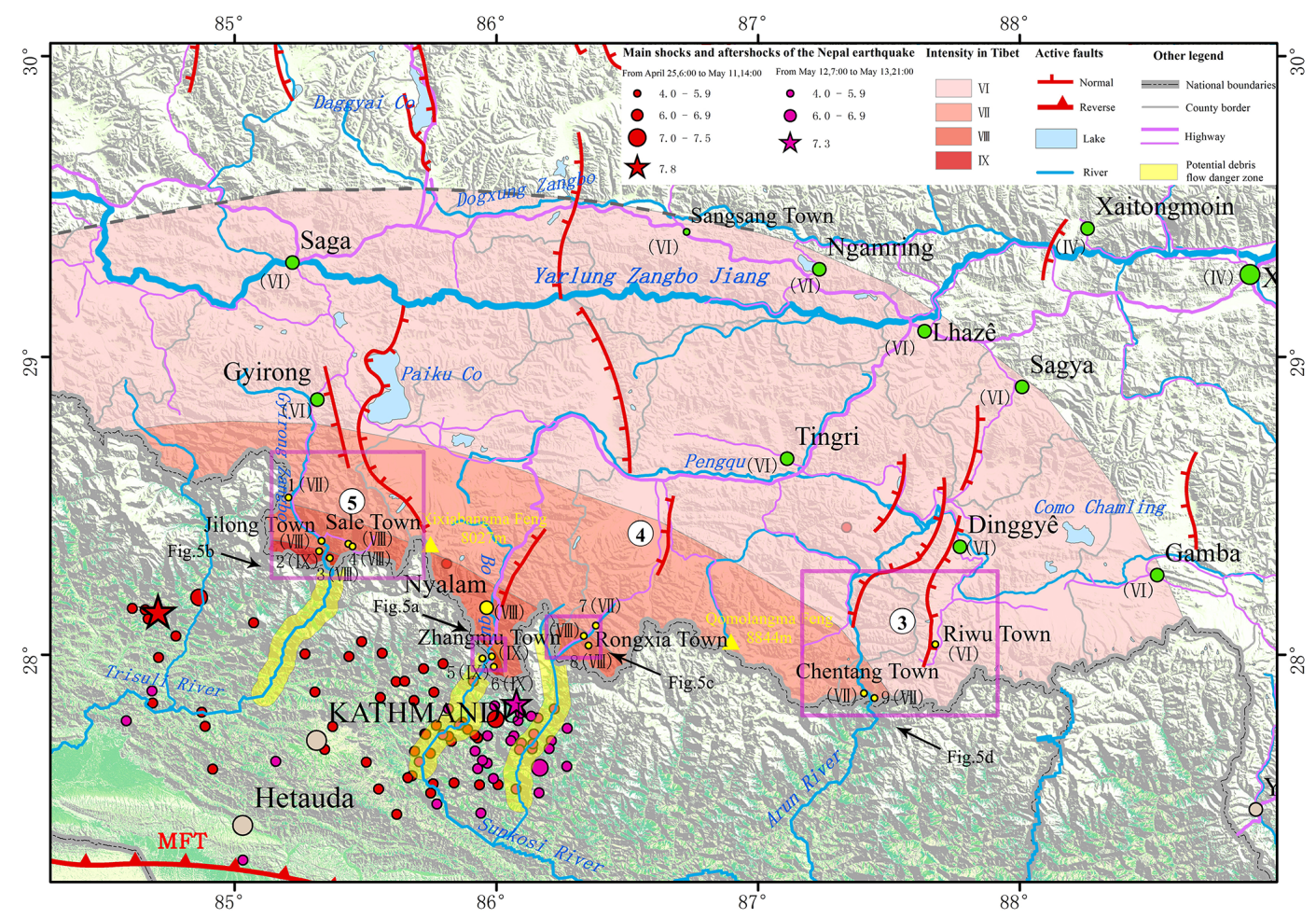

Figure 2. Principal active faults and the distribution of seismic intensity of the 2015 Nepal earthquake in the southern Tibet region. Epicentral data are from the USGS, and seismic intensity data are from the China Earthquake Administration. The numbers and names of the principal S-N-trending rifts in southern Tibet are same as on Fig. 1. The green circles show the sites of which intensities are from the China Earthquake Administration, and yellow circles show the spots of which intensities are resulted from our field investigation. The survey spots are denoted as follows: (1) Rema Village, (2) Jifu Village, (3) Chongse Village, (4) Guoba Village, (5) Kodari, Nepal, (6) Lixin Village, (7) Bangse Village, (8) Zhuobude Village, and (9) Natang Village.

remains dominant in the collision zone at the southern border of Tibet, south of the Himalaya Mountains, with the continued northward movement of India. Here the greatest activity occurs along the very shallow north-dipping Main Himalaya Thrust, which gave rise to the Nepal earthquake and has a long history of great earthquakes along its length (Fig. 1). Less generally known are a series of nearly $\mathrm{N}-\mathrm{S}$-trending normal faults and grabens to the north of the great thrust that complement some of the movement across it. These also are capable of producing significant earthquakes, although they are much shorter in length (Wu et al., 2011). This array of active faults plus a set of NW right-lateral strike-slip faults, which may aid extension, constitute the seismic framework of the region.

The China-Nepal border region is located on the south slope of the Himalaya Mountains close to the Main Himalaya Thrust and contains many active normal faults that control the transverse valleys that lead into Nepal. The high, rugged, steep topography and the well-developed incised river valleys in this region further amplify the destruction caused by earthquakes. Therefore, it is not strange that southern Tibet was greatly affected by the Nepal earthquake.

\section{Methods and data}

The intensity was evaluated using the Chinese seismic intensity scale (China Earthquake Administration, GB/T 177422008, 2008) (CSIS), which is a revised national standard implemented in 2009 , that has $12^{\circ}$ of intensity. This was modified from the GEOFIAN (Medvedev) scale, that in turn was adapted from the Modified Mercalli scale and is closely aligned with it, except in the lower units, and is approximately the same in the higher units reported on herein. The latest CSIS scale revision added an additional building type for evaluation in reflecting newer construction in the country (detailed information is provided in the Supplement).

A broad region of southern Tibet was affected by the earthquake, but the sparse population and difficult terrain did not permit the felt area to be defined well. Most isoseismals for the lower intensities were compiled by the China Earthquake Administration, which made a quick, overall survey of towns in order to assess the damage (Fig. 1). However, a detailed field survey, reported below, was made in the most affected region. The principal effects of the earthquakes are the damage suffered by structures, highways, and bridges and the landslides, collapses, and rockfalls. The landslips caused 
Table 1. Location of surveyed sites of earthquake intensity in southern Tibet. The .kmz file for these sites and some photos of typical housing damage are given in the Supplement.

\begin{tabular}{llll}
\hline Site & Coordinates & Intensity & Notes \\
\hline Lhasa City & $29.65^{\circ} \mathrm{N}, 91.12^{\circ} \mathrm{E}$ & III & felt area \\
Xaitongmoin Town & $29.432^{\circ} \mathrm{N}, 88.259^{\circ} \mathrm{E}$ & III & felt area \\
Xigazê City & $29.27^{\circ} \mathrm{N}, 88.88^{\circ} \mathrm{E}$ & IV & felt area \\
Nêdong City & $29.23^{\circ} \mathrm{N}, 91.76^{\circ} \mathrm{E}$ & IV & felt area \\
Gamba Town & $28.276^{\circ} \mathrm{N}, 88.516^{\circ} \mathrm{E}$ & VI & \\
Sa'gya Town & $28.903^{\circ} \mathrm{N}, 88.020^{\circ} \mathrm{E}$ & VI & \\
Lhazê Town & $29.087^{\circ} \mathrm{N}, 87.634^{\circ} \mathrm{E}$ & VI & \\
Ngamring Town & $29.298^{\circ} \mathrm{N}, 87.234^{\circ} \mathrm{E}$ & VI & \\
Sangsang Town & $29.420^{\circ} \mathrm{N}, 86.724^{\circ} \mathrm{E}$ & VI & \\
Saga Town & $29.329^{\circ} \mathrm{N}, 85.233^{\circ} \mathrm{E}$ & VI & \\
Gyirong Town & $28.856^{\circ} \mathrm{N}, 85.297^{\circ} \mathrm{E}$ & VI & \\
Tingri Town & $28.661^{\circ} \mathrm{N}, 87.122^{\circ} \mathrm{E}$ & VI & \\
Dinggyê Town & $28.367^{\circ} \mathrm{N}, 87.772^{\circ} \mathrm{E}$ & VI & \\
Riwu Town & $28.012^{\circ} \mathrm{N}, 87.681^{\circ} \mathrm{E}$ & VI & \\
Rema Village & $28.459^{\circ} \mathrm{N}, 85.224^{\circ} \mathrm{E}$ & VII & \\
Bangse Village & $28.083^{\circ} \mathrm{N}, 86.368^{\circ} \mathrm{E}$ & VII & \\
Rongxia Town & $28.057^{\circ} \mathrm{N}, 86.342^{\circ} \mathrm{E}$ & VII & \\
Chentang Town & $27.868^{\circ} \mathrm{N}, 87.414^{\circ} \mathrm{E}$ & VII & \\
Natang Village & $27.850^{\circ} \mathrm{N}, 87.441^{\circ} \mathrm{E}$ & VII & \\
Jilong Town & $28.396^{\circ} \mathrm{N}, 85.327^{\circ} \mathrm{E}$ & VIII & \\
Sale Town & $28.365^{\circ} \mathrm{N}, 85.445^{\circ} \mathrm{E}$ & VIII & \\
Guoba Village & $28.365^{\circ} \mathrm{N}, 85.457^{\circ} \mathrm{E}$ & VIII & \\
Zuobude Village & $28.037^{\circ} \mathrm{N}, 86.297^{\circ} \mathrm{E}$ & VIII & \\
Zhangmu Town & $27.990^{\circ} \mathrm{N}, 85.982^{\circ} \mathrm{E}$ & IX & \\
Disgang Village & $27.984^{\circ} \mathrm{N}, 85.979^{\circ} \mathrm{E}$ & IX & \\
Lixin Village & $27.960^{\circ} \mathrm{N}, 85.971^{\circ} \mathrm{E}$ & IX & \\
Kodari, Nepal & $27.972^{\circ} \mathrm{N}, 85.962^{\circ} \mathrm{E}$ & IX & \\
Jifu Village & $28.374^{\circ} \mathrm{N}, 85.329^{\circ} \mathrm{E}$ & IX & \\
Chongse Village & $28.373^{\circ} \mathrm{N}, 85.362^{\circ} \mathrm{E}$ & IX & \\
\hline
\end{tabular}

much of the damage to construction. Overall 2699 houses and one temple were destroyed, 39981 houses and 242 temples seriously damaged, and about $2600 \mathrm{~km}$ of main highways, 263 bridges, and a part of the communication, power, and water facilities were damaged to some degree in southern Tibet as reported by the China Earthquake Administration. In the region more closely studied in the field the damage and seismic intensity were evaluated at 29 sites in 10 affected counties (Fig. 2, and Table 1; see the Supplement for more information).

\section{Results}

\subsection{Damage features and seismic intensity}

Landslides, rockfalls, and collapses are common widespread occurrences during large earthquakes in the mountainous regions of Tibet. The Nepal earthquake was no exception, even though there was no nearby surface fault offset. The 2008 $M_{\mathrm{S}} 8.0$ Wenchuan earthquake and its aftershocks at the eastern border of Tibet produced hundreds of thousands of such landslips (Wang and Han, 2010; Tang et al., 2011; Yang et al., 2015). They caused major destruction and casualties, in addition to blocking river valleys and forming reservoirs that threatened downstream communities. It was only a massive emergency effort by the government that prevented additional major calamities. Several small dams were formed by the Nepal earthquake but no large ones that necessitated an emergency excavation, although the threat remains.

The perception of the earthquake, damage to buildings of different material and structure, and surface effects show obvious differences as recorded at the different levels of intensity. Only a few people in a room might have felt the earthquake in Lhasa at intensity III, whereas, to most of the people both inside and outside of buildings in Xigazê City, the earthquake was obvious, demonstrating an intensity of IV, and strong damage was indicated by an approximate intensity of IX at the Nepal border. The increasing and varying degrees of damage of buildings and disruptions of the surface in the VI to IX intensity zones were reviewed in the field in southern Tibet nearer Nepal (Table 1). The intensity described herein is a composite of both the main shock and the large aftershock. This may have caused an enhancement of the ratings if they were for the main shock alone because some structures weakened by it were further damaged or destroyed by the large aftershock.

Of the four counties investigated, Nyalam County is located on the south slope of the Himalaya Mountains, whereas Gyirong, Tingri, and Dinggye counties are located north of the mountains (for their seismic intensities, see Tables 1, 2). The main effects and economic loss are concentrated in Nyalam, Tingri, and Gyirong counties (Fig. 2), where about $80 \%$ of the houses were completely destroyed or damaged to a large extent (Figs. 3, 4). The damage is the heaviest in the towns of Zhangmu in Nyalam County, Jilong and Sale in Gyirong County, and Rongxia in Gyirong County (Fig. 5). Moreover, the highways and communications to the towns of Zhangmu, Tingri, and Resuo Bridge as well as connections to Zhangmu, Tingri, Chentang, and others in Nyalam County were greatly damaged and broken.

The Chinese intensity scale considers the varying effects on different building types, and this usually improves the reliability of the general intensity assignment, but locally it may lead to assigning different values, if there is a greater variation in damage than usual between types. This could be the case in these areas where the effects appear to reach either intensity VIII or IX depending on the type of structure used to assign intensity. The apparent highest intensity, IX, from destruction, that equaled some parts of Kathmandu, for older self-built stone masonry or adobe structures with poor seismic resistance, whereas for the newly built cement-bonded stone, brick, or concrete structures it was no more than intensity VIII, and the rating lies between (Figs. 3 and 4). For example, in Jifu Village about $2.4 \mathrm{~km}$ south of Jilong, all the houses built of stone block masonry were almost completely destroyed, whereas most newly built ones of cement-bonded stone or brick are still standing with only minor cracks in the walls (Fig. $4 c-d$ ), and the same variation is also seen at Sale 
Table 2. Distribution of seismic intensity in the southern Tibet region from the Nepal earthquake.

\begin{tabular}{|c|c|c|c|}
\hline Intensity & $\begin{array}{l}\text { Area } \\
\left(\mathrm{km}^{2}\right)\end{array}$ & City, county, and town covered by seismic intensity & Damage of buildings and surfaces \\
\hline IX & 105 & $\begin{array}{l}\text { The Zhangmu Town of Nyalam County, Jilong Town of } \\
\text { Gyirong County. }\end{array}$ & $\begin{array}{l}\text { Most of the mud brick and stone pile build- } \\
\text { ings were collapsed and severely damaged, and } \\
\text { some brick houses also have obvious damage } \\
\text { and partial collapse. Collapses and landslides } \\
\text { are widespread, as well as the existence of large } \\
\text { landslides. }\end{array}$ \\
\hline VIII & 1945 & $\begin{array}{l}\text { The Zhangmu Town and Nyalam Town of Nyalam } \\
\text { County, Jilong Town and Sale Town of Gyirong County, } \\
\text { Rongxia Town of Tingri County. }\end{array}$ & $\begin{array}{l}\text { Some of the mud brick and stone pile build- } \\
\text { ings were collapsed or severely damaged, but } \\
\text { the buildings of brick structure are mainly mod- } \\
\text { erately to slightly damaged and there are more } \\
\text { wall cracks. Medium and small collapses and } \\
\text { landslides are common but are rarely large. }\end{array}$ \\
\hline VII & 9590 & $\begin{array}{l}\text { Gyirong County, Nyalam County, Tingri County and } \\
\text { Dinggye County. }\end{array}$ & $\begin{array}{l}\text { A few of the mud brick and stone pile build- } \\
\text { ings were severely damaged, but most build- } \\
\text { ings are slightly damaged only. There are some } \\
\text { small collapses, landslides, and rockfalls along } \\
\text { the slope of valley and highway roadcuts. }\end{array}$ \\
\hline VI & 35460 & $\begin{array}{l}\text { Zhongba County, Saga County, Gyirong County, } \\
\text { Nyalam County, Tingri County and Dinggye County, } \\
\text { Gamba County, Sàgya County, Ngamring County and } \\
\text { Lhazê. }\end{array}$ & $\begin{array}{l}\text { Only a few mud brick and stone pile buildings } \\
\text { were slightly damaged, and collapses and land- } \\
\text { slides are rare. A small amount of rockfall may } \\
\text { appear near the highway roadcuts. }\end{array}$ \\
\hline Felt area & 300000 & Lhasa, Xigazê, Burang, Gar, and Nêdong, etc. & \\
\hline
\end{tabular}

Town Primary School (Fig. 4e). The inhabitants of this area had to be quickly moved to temporary settlements (Fig. 4b). Perhaps some poorer buildings weakened by the first earthquake were collapsed by the second one, or the newer buildings had more seismic resistance than realized. Some undetected ground slippage at a few locations throughout the region also may have augmented the effects to a slight degree.

The E-W elongation of the intensity pattern (Fig. 2, Tables 1,2 ) shows at least twice the rate of attenuation northward towards the Himalaya Mountains than in an E or W direction. This can be attributed to the absorption of the seismic energy by the E-W-trending fault structure and lithologic units of the great Himalaya Mountain block, plus a contribution from the E-W spread of the earthquakes and aftershocks.

The geologic effects caused by the Nepal earthquake are mainly landslides, terrace and loose material collapses, and debris flows, rockfalls, and ground fissures that were studied in detail at 33 sites in four towns in Nyalam, Gyirong, Tingri, and Dinggye counties (Figs. 2, 6). These vary with the intensity, amount of rock weakened by previous movement, steepness of slope, and lithology. These landslips diminish in number and size northward from the Nepalese border with the decrease in intensity. In the areas approaching intensity IX, landslides and collapses are widespread and include some large landslides; in the areas encompassing inten- sity VIII, small collapses and landslides were common, but large landslides were rare; intensity VII areas contain some small landslides, collapses, and rockfalls along valley slopes and roadcuts, whereas in the area of intensity VI small collapses and landslides are rare and a small amount of rockfalls occurred near roadcuts.

This damage has the following characteristics:

1. They are all disrupted slides, as classified by Varnes (1978; updated by Hungr et al., 2014), with a loss of internal cohesion.

2. They occur most densely along four incised river valleys, which are controlled by N-S-trending rifts that pass through the Himalaya Mountains and enter into Nepal (Fig. 2). The four valleys, successively from west to east, are the Gyirong Zangbo valley that follows the Gyirong graben and extends southwards (Figs. 5b and 6e), the Boqu River valley that follows the Nyalam graben and passes through Zhangmu and connects to the Sunkoxi River valley in Nepal (Figs. 5a and 6a), the Rongxiaqu valley that follows the southwest side of the Kong Co-Gangga graben to pass through Rongxia and descend to the Sunkoxi River valley in Nepal (Fig. 5c), and the Pengqu River valley, controlled by the Paiku Co rift, that crosses the Kung Co-Gangga graben and the Pengqu graben southwards and passes through Chen- 

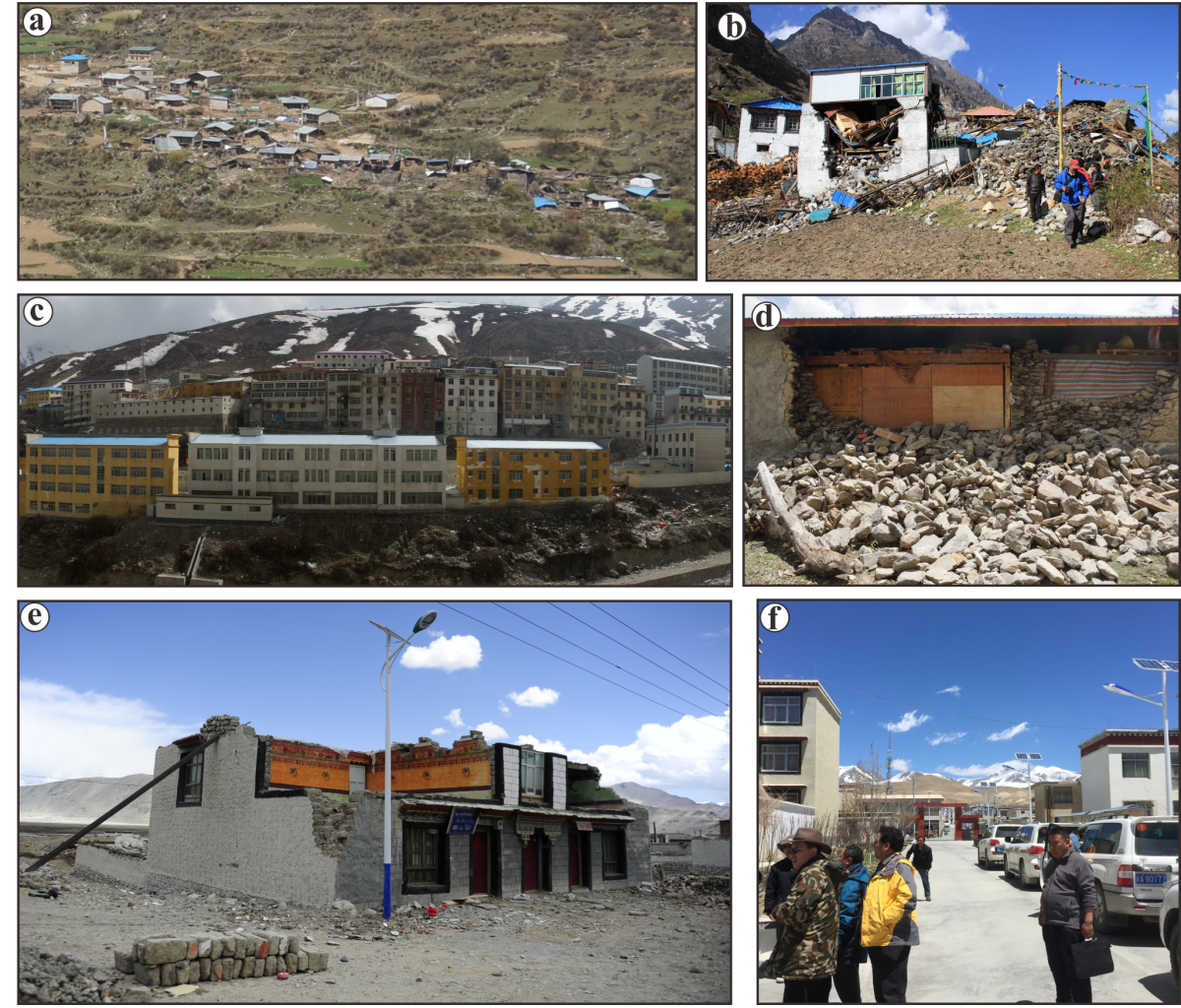

Figure 3. Building damage resulting from different earthquake intensities. (a) Many of the old stone pile or mud brick houses collapsed, but the new brick houses rarely collapsed at Gangba Village in Sale Town in the intensity VIII zone. (b) Similar building damage at Zhuobude Village of Rongxia Town in the intensity VIII zone. (c) Most buildings with a brick or concrete structure did not collapse, but many walls showed obvious damage at Nyalam City located in the intensity VIII zone. (d) Some walls of the stone pile or mud brick houses collapsed at Rema Village, Jilong County, in the intensity VII zone. (e) Similar building damage at Chentang Town, Dinggyê County, in the intensity VII zone. (f) Most of the houses remain intact, and only few or individual walls of buildings had apparent small cracks in Gyirong City in the intensity VI zone.

tang to connect to the Arun River in Nepal (Fig. 5d). The topographic relief in these valleys is generally about $2000-3000 \mathrm{~m}$, which is very conducive to various landslips during seismic events. Furthermore, there is an overall tendency for the number and size of collapses, landslides, and rockfalls to increase towards Nepal along these valleys. Remotely sensed images issued by Google Earth after the earthquake show that the Gyirong Zangbo and the Buqu River valleys were affected by the maximum density and scale of collapses and landslides (Figs. 5a, b, and 6a-h).

Moreover, some dammed lakes due to the collapsed rock and soil can be seen in these valleys of Nepal. For example, in the Gyirong Zangbo valley, a $0.07 \mathrm{~km}^{2}$ dammed lake and a $0.04 \mathrm{~km}^{2}$ dammed lake occur about $2.5 \mathrm{~km}$ north of and about $7.3 \mathrm{~km}$ southwest of Dhunche Village, respectively, and in the Boqu River valley, a $0.24 \mathrm{~km}^{2}$ dammed lake occurs on the north side of Dabi Village.
3. Damage often occurs in weak, soft geologic material and unstable geomorphic positions: joint or faultformed, high, steep bedrock cliffs and slopes (Fig. 6b and e); high, steep slopes of loose Quaternary sediment forming river terraces, proluvial fans, and benches (Fig. 6d and f); and unstable slopes and highway roadcuts (Fig. $6 \mathrm{~g}$ and $\mathrm{h}$ ). These landslides mostly occur on slopes steeper than $35-45^{\circ}$.

4. Most large ground fissures are associated with collapses and landslides. They either occur on the displaced masses or around their edges, and only a few such fissures occur on the surface of loose sediments (Fig. 8).

These rock and soil slips caused the most serious casualties and damage. The worst collapse found occurred in Disigang Village about $0.8 \mathrm{~km}$ southwest of Zhangmu, where about $0.016 \mathrm{~km}^{3}$ of debris destroyed four or five buildings and killed seven people (Figs. 4a, 6b, and 6c). The largest landslide found occurred about $1.3 \mathrm{~km}$ southwest of Chongse Village near Jilong, where about $2700000 \mathrm{~m}^{3}$ of material 

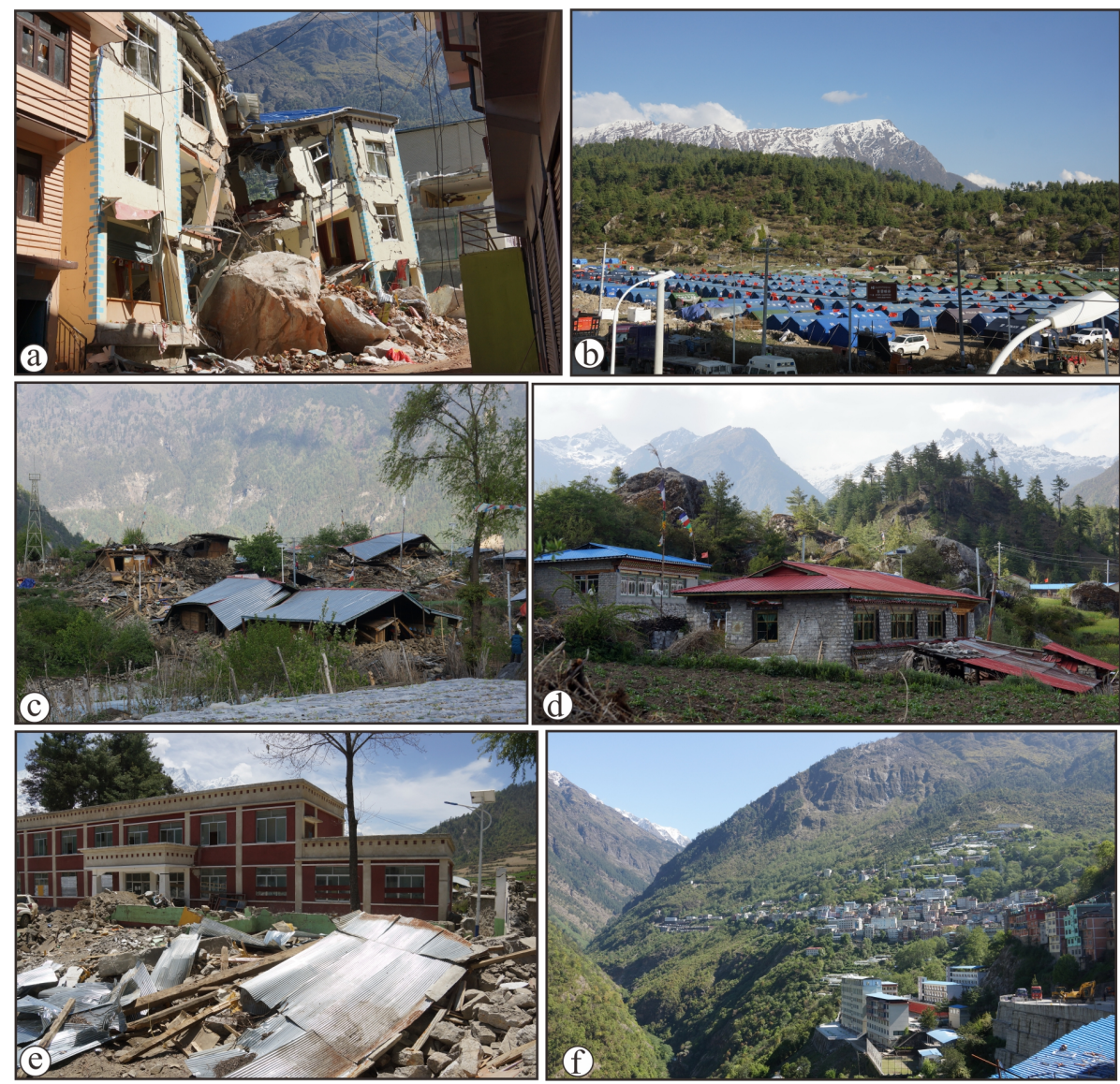

Figure 4. Typical earthquake damage in southern Tibet and comparison of houses of different construction (locations shown in Fig. 5). (a) Huge rockfall that smashed the resident committee office building at Disigang Village, about $0.7 \mathrm{~km}$ south of Zhangmu, where seven persons were killed (intensity IX) (site 1, Fig. 5a). (b) A temporary settlement for earthquake survivors at Jilong. (c) Destroyed houses of stone block masonry or adobe construction in Jifu Village southwest of Jilong (intensity VIII) (site 8, Fig. 5b). (d) Houses of cement-bonded stone or brick construction in Jifu Village (intensity IX). (e) Destroyed old houses and new buildings that are still standing at Sale Town Primary School (intensity VIII) (site 7, Fig. 5b). (f) Few collapsed houses at Zhangmu due to the brick structure or reinforced concrete construction (intensity IX).

blocked the main highway from Jilong to Gyirong Port (Fig. 6e). In addition, 27 small landslides and collapses occurred along the $14 \mathrm{~km}$ length of highway stretching from this landslide to Gyirong Port.

\subsection{Recurrence of seismo-geological hazards}

An important discovery was that the earthquake-induced landslide and collapse generally occurred where previous ones had taken place and correlated in size with the previous ones. This apparently reflects the effects of ancient earthquakes and provides new evidence for paleoseismicity, both in location and size. More significantly, this demonstrates that the areas of ancient landslide and collapse indicate the potential areas of danger from further landslips from torrential rains and future earthquakes, important considerations in seismic risk evaluation and the post-earthquake reconstruction process.
The collapses and landslides commonly result from reactivation of older ones, and similar effects produced by historic earthquakes occurred near the same position as in this earthquake. Such features are notable on both banks of the Boqu River near Zhangmu (Fig. 7a and b). At Disigang Village of Zhangmu, for example, a house built on the side of a large rock brought down previously was destroyed by a new large rockfall (Fig. 6c). This is a warning that reconstruction after the earthquake not only should avoid potential new hazards as far as possible but at the same time should be aware of previous ones and make a comprehensive assessment of their stability.

The specific structural damage is usually related to the material and type of building construction in these areas; the heaviest destruction occurred near the Nepal border. In this region with few trees, most of the houses are of simple stone and adobe construction, and these fared poorly during the earthquake, with the majority being destroyed near the Nepal 

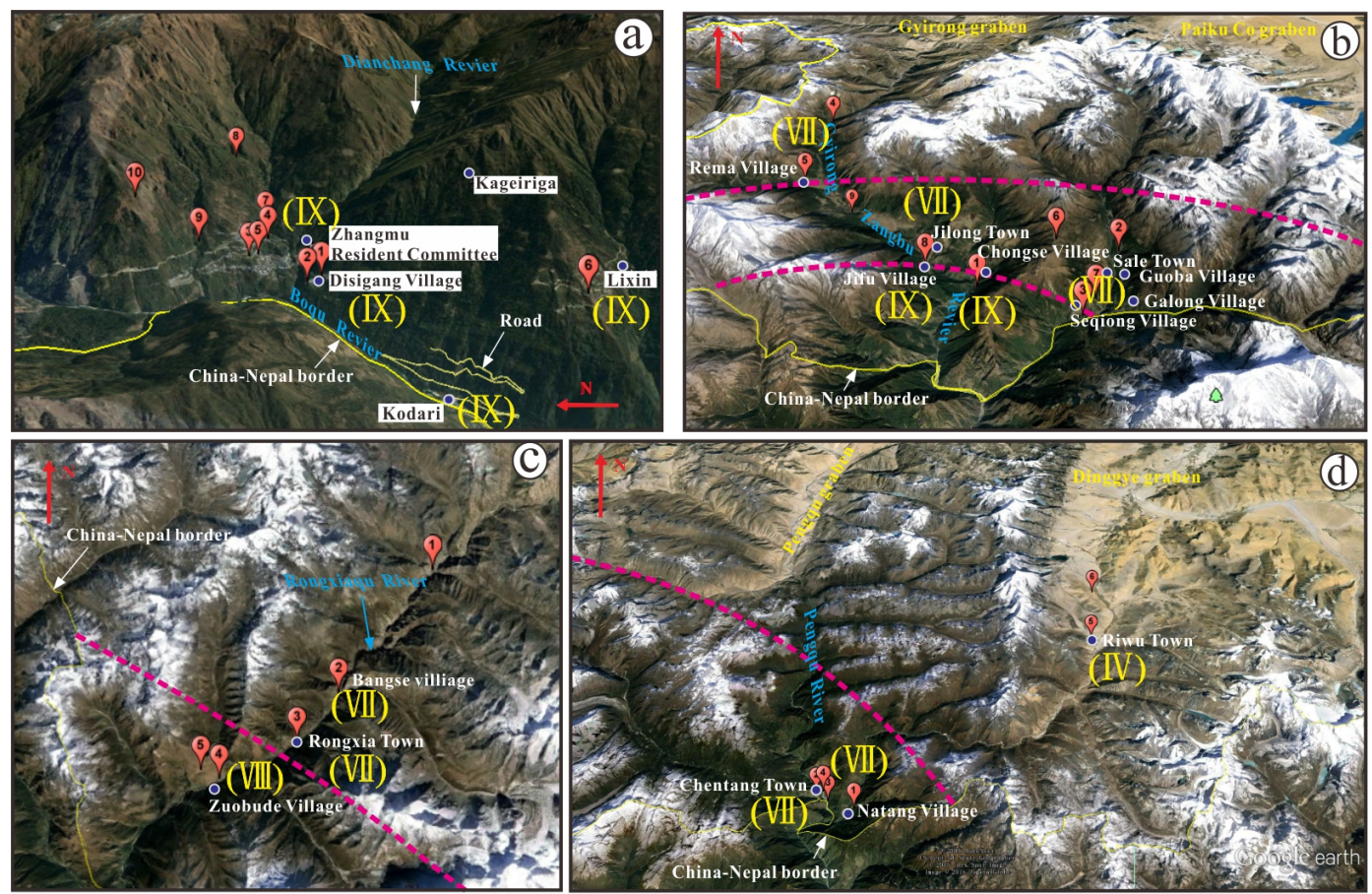

Figure 5. Main surveyed sites of seismic effects after the Nepal earthquake; see Fig. 2 for the locations (image source Google Earth). Roman numerals in brackets denote seismic intensity values of the corresponding location. Pink dotted lines show the boundaries between different intensity zones. (a) Zhangmu Town and vicinity. (b) Jilong Town and environs. (c) Rongxia Town and vicinity. (d) Riwu Town to Chentang Town. Numbered balloons denote sites which experienced significant effects. Red dashed lines show the isoseismal boundaries.

border (Figs. 3b, d, e, 4c). Houses with cement-bonded stone or brick construction survived much better (Figs. 3a, 4d), and those of good brick or reinforced concrete construction suffered the least (Figs. 3c, 4f) and provided a contrast with those of poorer materials (Figs. 3a, 4e).

\subsection{Post-seismic increased potential geological hazard}

The Nepal earthquake has left many potential dangers in its wake in this region, and nearby seismically active areas in southern Tibet that do not fit on an intensity scale yet are a consequence of the earthquake and pose a serious hazard that might create even greater damage and casualties than the immediate effects. The delayed effects in southern Tibet are the consequences of earthquake-loosened landslides and weakened rock that may fall due to aftershocks and torrential storms and from secondary earthquakes due to changes in the stress field resulting from the Nepal earthquake.

Rock, terrace material, and previous landslides loosened by the earthquake but still in place may fail with small aftershocks and torrential rains, which further weaken the material and add weight. Such an increase in secondary landslips during rainy seasons following earthquakes has been noted previously and is becoming a recognized hazard. Increased rainfall-triggered landslide activity above normal rates has been observed after several large earthquakes, two of which occurred in similar terrane to the east and west (Hovius et al., 2011; Saba et al., 2010; Tang et al., 2011; Dadson et al., 2004). Rain may even be a factor during an earthquake. Data in New Zealand suggest that earthquakes that occur during wetter months trigger more landslides than those during drier periods, although a clear relationship between rainfall-induced pore pressure and earthquake-induced landslide triggering has not been shown (Dellow and Hancox, 2006; Parker et al., 2015). When Typhoon Toraji hit Taiwan following the $2005 M_{\mathrm{w}}$ 7.6 Chi-Chi earthquake, 30000 more landslides occurred, with many being reactivated ones triggered by the earthquake, although $80 \%$ of the Toraji landslides occurred in areas that had not failed during the earthquake (Dadson et al., 2004). The proportion of surface area disturbed by the landslides increased towards the active fault, suggesting that even in areas that underwent no landslips during the earthquake, the substrate was preconditioned to fail through loss of cohesion and frictional strength of hill slope rock mass caused by the strong seismic motion (Dadson et al., 2004).

A similar general weakening of rock strength was deduced in the mountainous region of South Island, New Zealand, where to test the possible influence of previous earthquakes in preconditioning the ground for landsliding, the areas of overlap of high intensity of similarly strong, $>M_{\mathrm{w}} 7,1929$ and 1968 earthquakes were compared (Parker et al., 2015). Many landslides produced in 1968 were reactivations or en- 

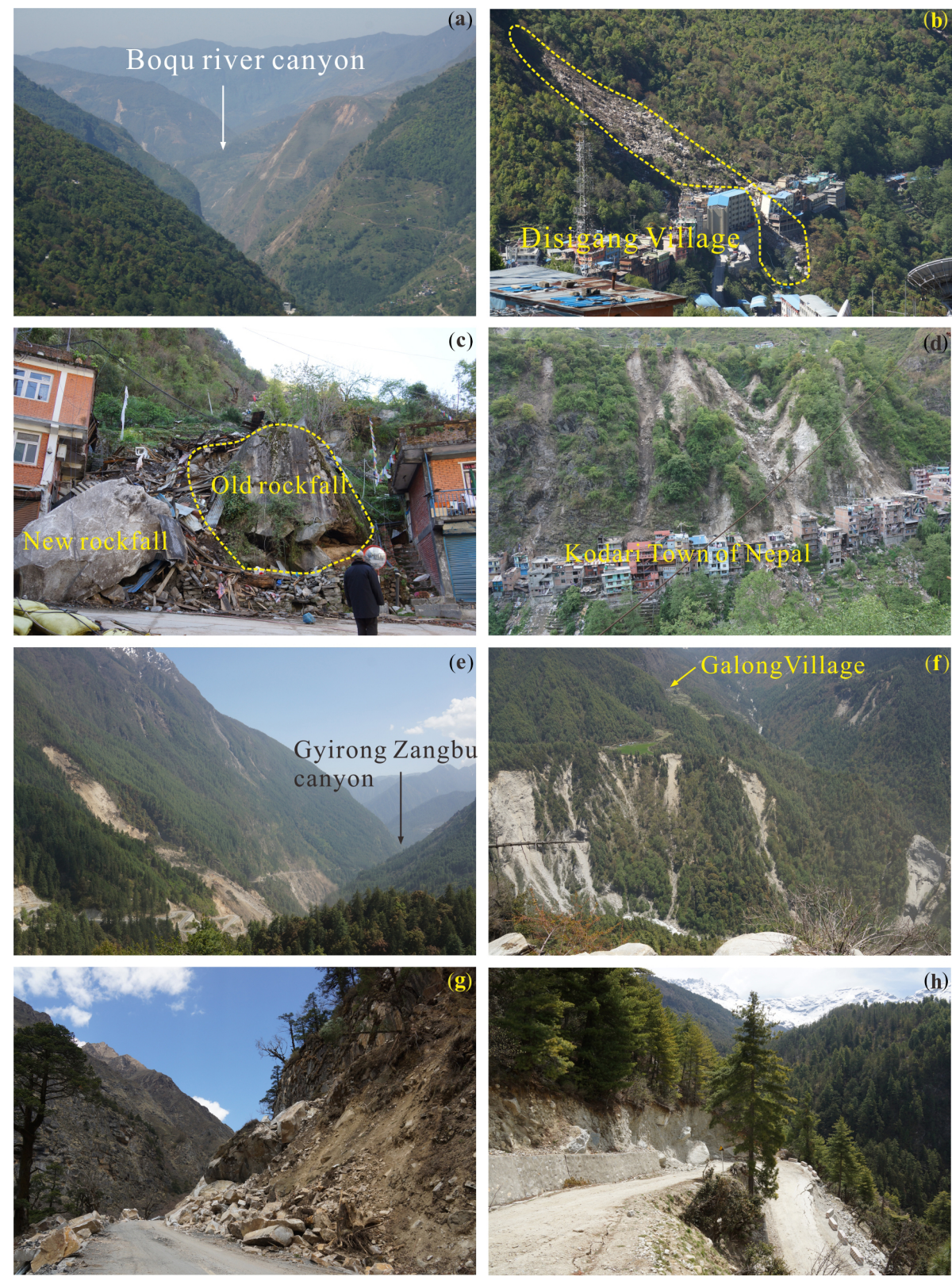

Figure 6. Geologic effects caused during the Nepal earthquake: (a) collapses in the Boqu valley; (b) collapse at Disigang Village in the Boqu valley (site 1, Fig. 5a); (c) new and old rockfalls at Disigang Village in the Boqu valley (site 1, Fig. 5a); (d) destroyed buildings in Kodari, Nepal, in the Boqu valley (site 1, Fig. 5a); (e) large landslide in Chongse Village in the Gyirong Zangbo valley (site 1, Fig. 5b); (f) collapses in Galong Village in the Gyirong Zangbo valley (site 7, Fig. 5b); (g) collapses along the highway from Gyirong County to Jilong Town in the Gyirong Zangbo valley (site 4, Fig. 5b); and (h) collapses and fissures along the highway from Jilong to Chongse Village in the Gyirong Zangbo valley (site 1, Fig. 5b).

largements of ones that failed in 1929, but others were not, although there was a higher degree of failure in the overlapped area than could be easily explained in considering all the factors normally involved in landslip. These observations suggested that hill slopes may retain damage from past earthquakes, which makes them more susceptible to failure in future triggering events, and this influenced the behavior of the landscape in the 1968 earthquake. It was further suggested that the damage legacy of large earthquakes may persist in parts of the landscape for much longer than the observed less than 10-year periods of post-seismic landslide activity and sediment evacuation.

Similarly, data from the $2010 M_{\mathrm{w}} 7.1$ Canterbury-2011 $M_{\mathrm{S}} 6.3$ Christchurch earthquake sequence reveal landslide triggering at lower ground accelerations following the February 2011 earthquake, which caused cracks to develop in hill 
slopes that subsequently failed in later earthquakes in the sequence (Massey et al., 2014a, b; Parker et al., 2015).

This general loosening of rock through ground motion also occurred at the Nevada test site, where deep underground nuclear explosions, similar to shallow earthquakes, caused widespread movement along joints within the overlying bedrock. Some fractures were propagated upward through $610 \mathrm{~m}$ of alluvium to demonstrate how even this soft material was weakened further.

The progressive brittle damage accumulation in hill slope materials may lead to permanent slope displacement that results in cracking and dilation of the mass, which makes them more susceptible to failure (Petley et al., 2005; Nara et al., 2011; Bagde and Petroš, 2009; Li et al., 1992; Parker et al., 2015). Whether or not a hill slope fails in response to an earthquake thus becomes a function of both a current event and the history of damage accumulated from previous events (Parker et al., 2015).

These later landslides pose all of the same dangers as those occurring during the initial earthquake and also may cause damming of rivers to create dangerous reservoirs that can fail with devastating effects.

The landslips also increase the hazard from flooding in the disturbed region. They contribute debris to valleys to widen them and raise river beds, which greatly raises the flood danger as has happened in the region of the Wenchuan earthquake since 2008 (Yang et al., 2015). This is a problem that needs to be recognized in post-earthquake reconstruction.

Such consequences from earthquakes are long-lasting. It is estimated to have taken 3 years for the Kashmir earthquake region to recover, 6 for the Chi-chi earthquake, over 7 for the Wenchuan earthquake and even longer for others (Saba et al., 2010; Yang et al., 2015; Dadson et al., 2004).

There is a worry of additional landslides and rockfalls after the Nepal earthquake, especially of large ones, that might block river valleys and impound water. Indeed, both the number and range of collapse and rockfall have clearly increased in the year's rainy season following the earthquake. (Chengcan Zhou, personal communication, 2015) noted that before the earthquake, collapses and rockfalls only occurred on steep hill slopes on both sides of the Boqu River north of Zhangmu Town, but now they take place along the entire highway in this area. He reports that the increased hazard has caused many road closures and damaged vehicles but no casualties as yet because the town was evacuated after the earthquake. The increased hazards are mainly distributed nearby along the highway between Nyalam to Zhangmu where 18 major landslide groups were identified after the earthquake by the National Disaster Reduction Center of the Ministry of Civil Affairs using high-resolution remote sensing images. Such an increase in the number of slides should be widespread in several major valleys of southern Tibet, but relatively few have been reported due to scarce personnel and poor transportation and communication.
Unstable masses found to date are the reactivated landslide group at Zhangmu, collapse of the upper edge of the Sale Village landslide in Sale, potential failure of the dangerous rock mass at Rongxia Primary School, and instability of the old Natang Village landslide and its upper edge at Chentang Town.

All of Zhangmu is located on a group of old landslides (Figs. 4a, 7a, and 7b). Discontinuous tension fissures, which are tens to hundreds of meters long, about $10 \mathrm{~cm}$ wide and 2 to $4 \mathrm{~m}$ deep, were found at its upper edge and on its sides after the earthquake (Fig. 8a and b). These fissures indicate the possibility of the failure of the entire landslide group.

The Sale Village landslide resulted from the earthquake on the slope along the highway from Sale Village to Seqiong Village (Fig. 5b). It was nearly $600000 \mathrm{~m}^{3}$ in volume and its fall blocked the road. Large tension fissures at its upper edge indicate a danger of further slippage (Fig. 8c).

The dangerous rock mass at Rongxia Village Primary School occupies a convex portion of the cliff behind the school and appears unstable (Figs. 5c and 8d). A rockfall occurred here during the earthquake, but the fall appears to have been incomplete and left a cliff that lacks stability and is susceptible to further rockfall.

Natang Village near Chentang is located at the front, lower edge of an old landslide, which is about $420 \mathrm{~m}$ long and $230 \mathrm{~m}$ wide and consists of an area of about $1200000 \mathrm{~m}^{3}$ (Figs. 5d and 8e). The steep wall at its upper edge appears as two large dangerous rock blocks which are about $60000 \mathrm{~m}^{3}$ in volume, and a $1.7 \mathrm{~m}$ wide preexisting crack occurred between the unstable rock blocks and the bedrock (Fig. 8f). The earthquake caused a partial rockfall and demonstrates the dangerous instability of the mass that might fall easily.

The danger of post-seismic debris flows also must be stressed; although these were rare for this earthquake in the southern Tibet region, they were a serious problem after the Wenchuan earthquake (Cui et al., 2010; Tang et al., 2011). There is, however, a considerable amount of loose debris accumulated in mountain valleys and gullies that could provide material for further debris flows, especially on the south slope of the Himalaya Mountains. Rainfall, which provides excessive water to lubricate land slips and adds weight to a loose mass, is a key factor in inducing post-seismic debris flows as well as triggering landslides and rockfalls. There is a large difference in rainfall between the south and north slopes of the Himalaya Mountains. The annual average rainfall at Zhangmu on the south slope is up to $2556.4 \mathrm{~mm} \mathrm{a}^{-1}$, whereas the annual average rainfall in Jilong and the seat of Nyalam County on the north slope is only 880.3 and $654.0 \mathrm{~mm} \mathrm{a}^{-1}$, respectively. The rainfall on the south slope was concentrated in the Indian Ocean summer monsoon season, and induced debris flows were already being reported in Nepal at the beginning of June. The several incised valleys in the south mentioned above are sites of potentially dangerous post-seismic debris flows in Tibet, particularly in the three deeply incised valleys leading toward Nepal that have a high potential for 

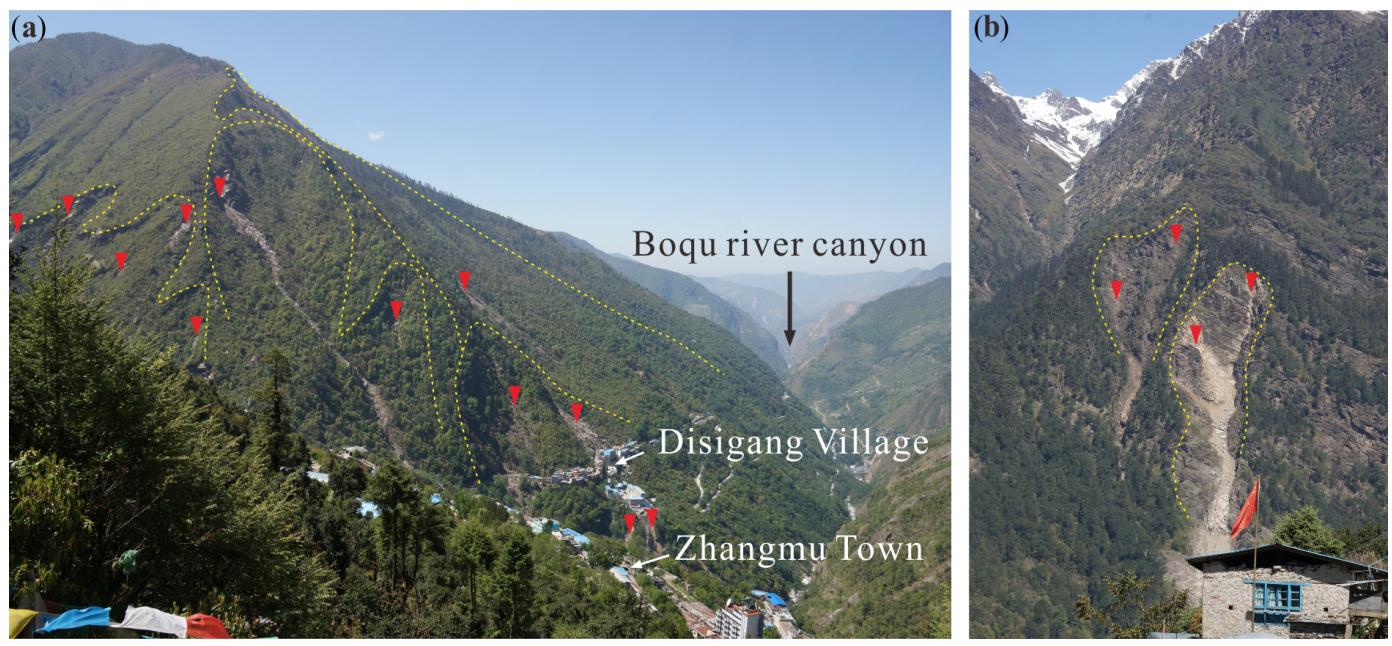

Figure 7. New and old collapses and landslides on both banks of the Boqu River in Zhangmu Town: (a) the east bank and (b) the west bank. The yellow dotted lines show the boundaries of old collapses and landslides. The red triangles denote new collapses during the Nepal earthquake.

flows that could dam the rivers to form dangerous lakes. These valleys, from west to east, are the Gyirong Zangbo River in the upper basin of the Trisuli River, the Boqu River, and the Rongxiaqu River in the upper basin of the Sunkoxi River (Fig. 2). Another danger spot is in the Dianchang gulley on the south side of Zhangmu (Figs. 5a and 7a), where considerable loose debris is in a very unstable state.

\section{Discussion}

\subsection{Pattern of damage}

The Nepal earthquake was felt over a wide region of southern Tibet. Fortunately, few casualties occurred because of the sparse population, but there was extensive damage due to the presence of many poorly built stone and adobe buildings and the impact of landslides, collapses, and rockfalls in this steep mountainous region of high relief that is similar to the Nepal region (Zekkos et al., 2017); the intensity near the Nepal border approached IX. The intensity distribution showed that the attenuation rate northward was more than twice that in either eastward or westward directions due to the absorption of energy by the major E-W-trending structure of the region and the trend of the seismic activity in the epicentral area. The intensity survey demonstrated a very wide difference in seismic performance between these poorly built buildings and well-built brick and concrete ones. In addition to the immediate damage shown by the intensity, there are the delayed effects of further dangerous land movement and an increased potential for a significant earthquake over the next several years, all of which are important in consideration of the seismic hazard in the region and post-earthquake reconstruction.
The numerous landslides, collapses, and rockfalls occurred on slopes steeper than $35-45^{\circ}$ and usually at locations where previous ones took place. This seems to reflect the effects of ancient earthquakes and provides new evidence for paleoseismicity. The presence of large landslides, which either did not fail or only partially so, also suggests that larger earthquakes affected this region in the past. These sites of ancient and modern slips mark the hazardous areas in future earthquakes, an important consideration in seismic risk evaluation and the post-earthquake reconstruction process.

The Nepal earthquake both changed and brought out features that enhance the seismic hazard in the near and long term. The principal geologic dangers emanate from landslides, collapses, and rockfalls in this steep terrane from ones loosened or which only partially failed immediately or new ones from ground weakened by the general ground shaking of the earthquake. These will be more common in the next 3 to 6 years or so as a delayed effect of the earthquake, especially in seasons of heavy rainfall. All of the areas of older landslips, whether or not they reactivated in this earthquake, are susceptible to reactivation and are particularly dangerous. In recent years it has been discovered that ground motion from large earthquakes results in weakened cohesiveness of the ground and causes more abundant landslips subsequently. These may clog valleys to form dangerous reservoirs. Such an increase in landslips has already been noted in the study area this past summer.

Both the landslips during an earthquake and the delayed ones contribute debris to the river valleys which widens them and raises riverbeds to create conditions which are conducive to flooding.

This can destroy additional buildings and endanger bridges as in the area of the Wenchuan earthquake (Yang et al., 2015). 

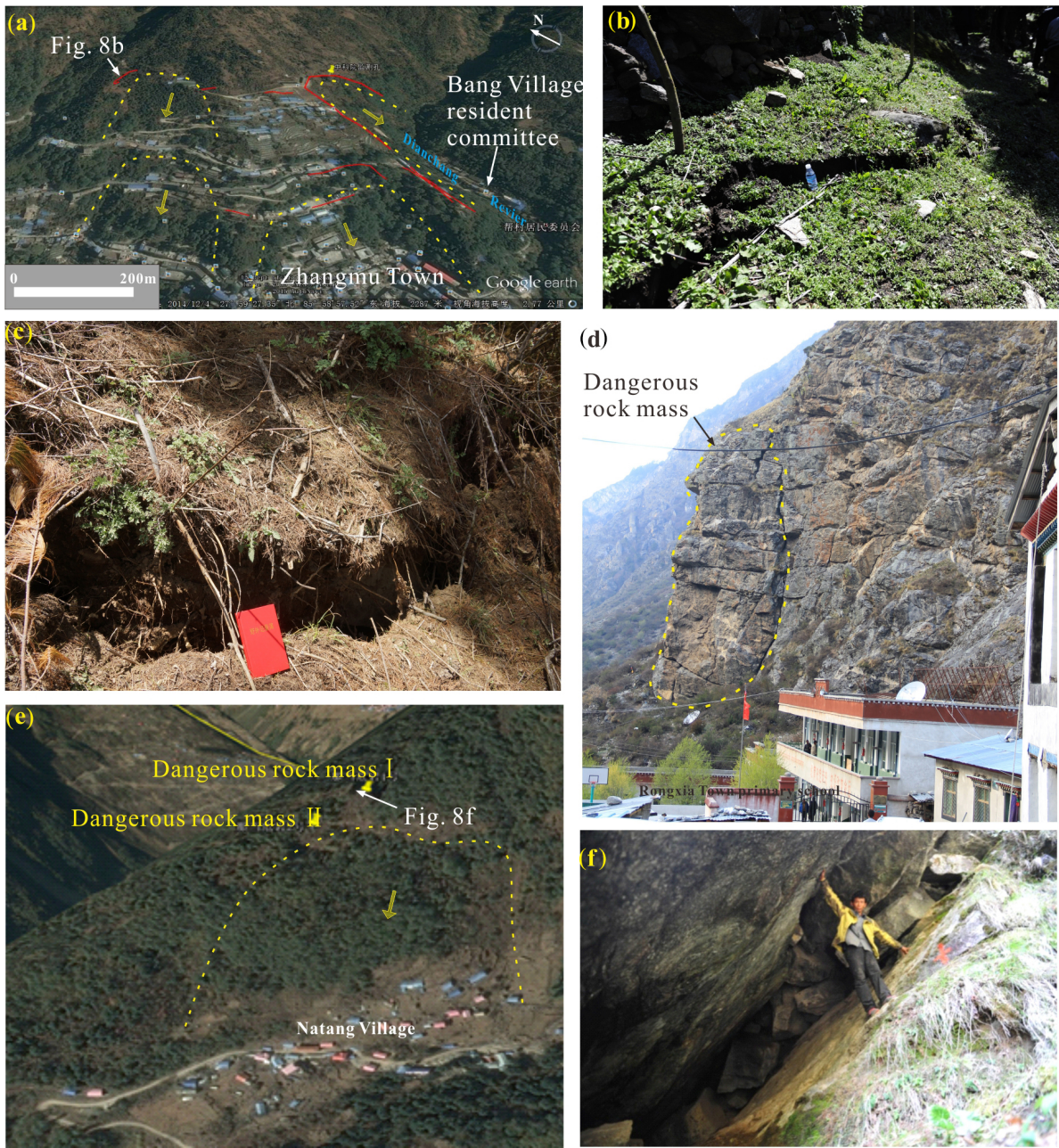

Figure 8. Fissured and unstable rock masses formed by the earthquake that indicate hazards for additional landslides and rockfalls. The yellow dotted lines show the landslide group. Arrows denote the slip direction, and the red line denotes new fissures formed during the Nepal earthquake. (a) Old landslide group at Zhangmu. (b) New fissure in the old landslide group at Zhangmu (Fig. 8a). (c) Tension fissures at the back edge of Sale Village landslide (site 7, Fig. 5b). (d) Dangerous rock mass at Rongxia Primary School (site 3, Fig. 5c). (e) Old landslide with unstable rock at Chentang Town (site 1, Fig. 5d). (f) Fissure between unstable rock and bedrock at Chentang (Fig. 8e).

Following these characteristics, we should focus on three circumstances in the assessment of seismic geological hazards (mainly referring to collapse, landslips, and rockfall here) within areas that are affected by many strong earthquakes and high relief:

1. steep slopes formed by loose bodies, such as thick alluvial and residual deposits, in deep valleys;

2. places with multiple periods of landslides, collapses, and rockfalls;

3. the revived possibility of known landslides and collapses in future earthquakes.

\subsection{Relationship between the MHT and N-trending rifts}

The Nepal earthquake has likely set the stage for another forceful nearby earthquake that can be considered a delayed effect. The release of energy in a great earthquake such as the Nepal earthquake may shift the strain to the adjacent regions where other earthquakes may then occur, such as the strong earthquakes that occurred in Tibet following the $M_{\mathrm{s}}$ 8.0 Wenchuan earthquake (Wu et al, 2011). The seismic history of the southern border of Tibet appears to bear this out. Large earthquakes along the south margin on the Main Frontal Thrust of the Main Himalayan Thrust are followed by ones along the $\mathrm{N}-\mathrm{S}$-trending normal faults in the region to the north (Fig. 1). There now is an increased concern that 
a significant earthquake may occur along the normal faults in the region based on this recent history.

Southern Tibet is an earthquake-prone region with long E$\mathrm{W}$-trending active thrust faults such as that which caused the Nepal earthquake; less well known are the important active normal faults and grabens just to the north (Figs. 1 and 2). These normal faults form at least eight nearly N-S-trending rifts across southern Tibet. Geological estimates and GPS data show that the E-W extension rates across the rifts were 10-13 $\mathrm{mm} \mathrm{a}^{-1}$ during the Quaternary and Holocene (Armijo et al., 1986; Chen et al., 2004). Such rates are close to the Holocene slip rate of $21 \pm 1.5 \mathrm{~mm} \mathrm{a}^{-1}$ along the Main Frontal Thrust of the Main Himalaya Thrust (Lavé and Avouac, 2000) and to the recent GPS-based shortening rate of 10$19 \mathrm{~mm} \mathrm{a}^{-1}$ across the Himalaya orogenic belt (Larson et al., 1999; Jouanne et al., 1999; Zhang et al., 2004; Bettinelli et al., 2006). There thus appears to be a close kinematic connection between the thrusting on the Main Himalaya Thrust and the nearly N-S-trending normal faulting in the southern Tibet region as indicated by the historic seismicity (Armijo et al, 1989; Molnar and Lyon-Caen, 1989).

Often within a short time interval of about 1 to 10 years after great earthquakes on the Main Himalaya Thrust, strong earthquakes occur on the N-S-trending normal faults in the southern Tibet region (Fig. 1, 9a). For example, the great Kashmir earthquake of 1400 was followed by a $M 8.0$ earthquake in the Damxung-Yangbajain sector of the northern Yadong-Gulu rift in 1411, a $M 8.1$ earthquake in the western part of Nepal in 1803 was followed by a $M 7.5$ earthquake in the southern sector of the Cona-Oiga rift in 1806, and the $M 7.8$ Kashmir earthquake of 1905 was followed by a $M 7.5$ earthquake at Sangri in the northern sector of the Cona-Oiga rift in 1915. Similarly, after the $M 8.11934$ Nepal earthquake, a $M 7.0$ earthquake in the same year occurred in the N-S-trending Gomang Co graben in northeastern Xainza County, and after the 1950 M 8.6 China-Indian border earthquake, a $M 7.5$ earthquake occurred in 1952 in the northern sector of the Yadong-Gulu rift in Nagqu County.

Another delayed effect of the earthquake is the enhanced seismic hazard due to the release in energy and the shift in strain, based on the past seismic history. The Nepal earthquake emphasizes the close relation between the seismic activity and the dynamics in the nearly east-west stretch of deformation along the Himalaya foothills and the controlling activity along the Main Himalaya Thrust, which triggered the Nepal earthquake. Extensional forces that are about perpendicular to the active thrust have a history of resulting in a nearby significant normal fault earthquake following thrust movement within the subsequent 10 years that results in further destruction and fatalities. Some normal fault activity has indeed been noted in the aftershocks of the Nepal earthquake but not nearly enough to release the expected strain (Fig. 9b).

On the first and second day after the 2015 Nepal earthquake a $M_{\mathrm{w}} 5.4$ earthquake occurred in Nyalam County and a $M_{\mathrm{s}} 5.9$ earthquake in Tingri County, respectively. Both are nearly N-S-trending normal faulting-type earthquakes: the former occurred in the Nyalam-Coqên rift and the latter at the southern end of the Xainza-Dinggye rift. However, these movements are unlikely to have released all the built up extensional force. Recently, Elliott et al. (2010) found from the InSAR and body wave seismological images of normal faulting earthquakes that the extension rate due to the contribution of the seismic energy released through normal faulting for the past 43 years in the southern Tibet region is $3-4 \mathrm{~mm} \mathrm{a}^{-1}$, which is only equivalent to $15 \%-20 \%$ of the extension rate obtained by GPS measurements. This suggests that there still is about $80 \%$ of the energy due to extension to be released, possibly as near-future seismic activity.

The extension also may affect a set of NW-trending rightlateral strike-slip fault zones that have significant activity in the southern Tibet region. These are, from west to east, the Karakorum fault zone, the Gyaring Co fault zone, and the Beng Co fault zone (Fig. 1). Their Quaternary strike-slip rate may reach 10-20 $\mathrm{mm} \mathrm{a}^{-1}$ (Armijo et al., 1989; Chevalier et al., 2005). Such faults with high strike-slip rates also can play an important role in adjusting the nearly E-W extensional deformation in the area. For example, a $M 8.0$ earthquake in southwestern Nagqu in 1951, which occurred along the NW-trending Beng Co fault zone, followed the 1950 M 8.6 Zayü earthquake of eastern Tibet that is known in India as the Assam earthquake.

Based on past experience, the southern Tibetan region in the vicinity of the Nepal earthquake is likely to have a normal fault earthquake within the next 10 years.

\subsection{Suggestions for regional earthquake prevention and disaster mitigation}

This investigation is preliminary and generalized, but tentative recommendations can be issued to guide reconstruction in the region.

First, southern Tibet is a region with remarkable historical seismicity where earthquakes and their effects cannot effectively be forecast, but a reevaluation of the earthquake hazards should be made as soon as possible to indicate the potential dangers noted in this survey.

Second, the relocation and reconstruction of damaged residential areas need to consider the potential dangers of postseismic hazards and stability of previous seismically induced geologic effects. Areas of ancient landslides, collapse, and rockfall, in particular, need to be mapped and avoided, especially for schools, hospital, utilities, and vital government buildings and, where possible, roads and bridges. Bridges might be rebuilt higher in valleys where riverbeds may be raised and the flood danger enhanced due to increased debris flow from the displaced material. And for the same reason, selection of building sites in valleys must be chosen with care. A wide selection for new, safer sites for construction should be provided in the vast southern Tibetan region with its very low population density. 

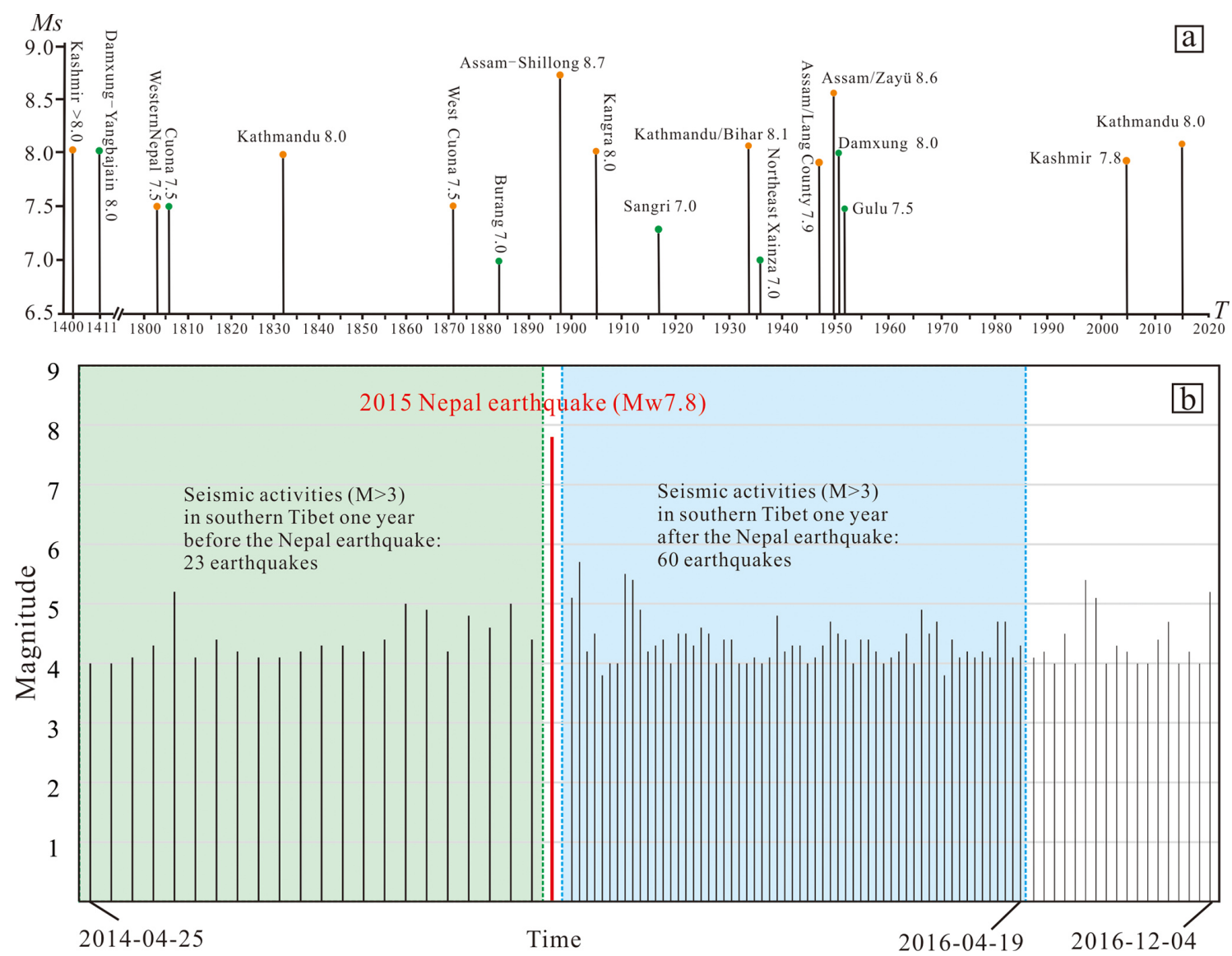

Figure 9. (a) Magnitude-time $\left(M_{\mathrm{S}}-T\right)$ distribution of historical seismic activity along Himalaya and southern Tibet with the magnitude $>7.0$. The orange circles show the earthquakes that occurred along Himalaya, while the green circles show the earthquakes along the southern Tibetan rift. (b) Magnitude-time $(M-T)$ distribution of seismic activity in southern Tibet in the period of 1 year before and after the 2015 Nepal earthquake (data are from USGS).

Third, in the repair and reconstruction of buildings, new anti-seismic construction codes must be adopted. The replacement of poorly built stone and adobe building by more seismic resistant brick and concrete ones should be given a high priority.

Fourth, over the next 10 years there should be heightened awareness and preparations for a possible earthquake in one of the grabens of southern Tibet.

Finally, although more detailed seismic-geological study is, of course, necessary, greater urgency should be directed at the construction of better anti-seismic buildings and facilities in areas away from potential geological hazards that may be triggered by earthquakes.

\section{Conclusions}

1. Damage caused by the Nepal earthquake in Tibet varies with the intensity, amount of rock weakened by previous movement, steepness of slope, and lithology. And the damage shows that directional features mainly de- veloped in the N-trending rifts in southern Tibet. However, the damage was not related to the faulting of $\mathrm{N}$ trending rifts.

2. The earthquake-induced landslides and collapses generally occurred where previous ones had taken place and were correlated in size with the previous ones. Therefore, the areas of ancient landslide and collapse indicate the potential areas of danger from further landslips from torrential rains and future earthquakes.

3. The directional features, paleo-earthquakes, and deformational rate of damage also suggest that the E-W extensional deformation in southern Tibet is closely associated with the Himalaya thrust fault. Then, the activity of the MHT could trigger the active faulting of $\mathrm{N}$-trending rifts.

Data availability. Most of the data are made available in tables and the Supplement of this paper (note that there are no data beyond articles and supplements). 
Supplement. The supplement related to this article is available online at: https://doi.org/10.5194/nhess-19-873-2019-supplement.

Author contributions. ZW and PJB conceived and prepared the entire paper, GH collated and analyzed the earthquake data related to the nearly N-S trending normal faulting in southern Tibet, XY and YX participated in the field survey and provided some data of earthquake-induced geo-hazards, and JL collated seismic data from the Himalayan belt and seismic intensity data from southern Tibet.

Competing interests. The authors declare that they have no conflict of interest.

Acknowledgements. This work was supported by the National Natural Science Foundation of China (no. 41571013 and 41171009). We would like to thank Tingshan Tian and Jietang Lu of the China Institute of Geo-environment Monitoring, Qiang $\mathrm{Xu}$ and Guang Zheng of the Chengdu University of Technology, and Ji Duo and Baoben Xia of the Geology and Mineral Resources Exploration Bureau of Xizang Autonomous Region for their participation of our field investigation. We also appreciate the help extended by the Department of Land and Resources of Xizang Autonomous Region and relevant local governments.

Review statement. This paper was edited by Maria Ana Baptista and reviewed by five anonymous referees.

\section{References}

Armijo, R., Tapponnier, P., Mercier, L., and Han. T. L.: Quaternary extension in southern Tibet: Field observation and tectonic implication, J. Geophys. Res., 91, 13803-13872, 1986.

Armijo, R., Tapponnier, P., and Han, T. L.: Late Cenozoic rightlateral strike-slip faulting in southern Tibet, J. Geophys. Res., 94, 2787-2838, 1989.

Avouac, J. P.: Dynamic processes in extensional and compressional settings - mountain building: from earthquakes to geological deformation, Treatise on Geophys., 6, 377-439, 2007.

Bagde, M. N. and Petroš, V.: Fatigue and dynamic energy behaviour of rock subjected to cyclical loading, Int. J. Rock. Mech. Min., 46, 200-209, 2009.

Bettinelli, P., Avouac, J. P., and Flouzat, M.: Plate motion of India and interseismic strain in the Nepal Himalaya from GPS and DORIS measurements, J. Geod., 80, 567-589, https://doi.org/10.1007/s00190-006-0030-3, 2006.

Bijukchhen, S., Takai, N., Shigefuji, M., Ichiyanagi, M., and Sasatani, T.: Strong-Motion Characteristics and Visual Damage Assessment Around Seismic Stations in Kathmandu After the 2015 Gorkha, Nepal, Earthquake, Earthq. Spectra, 33, S219-S242, https://doi.org/10.1193/042916EQS074M, 2017.

Bilham, R.: Earthquakes in India and the Himalaya: tectonics, geodesy and history, Ann. Geophys., 47, 839-858, 2004.
Chen, Q. Z., Freymueller, J. T., Yang, Z. Q., Xu, C. J., Jiang, W. P., Wang, Q., and Liu, J. N.: Spatially variable extension in southern Tibet based on GPS, J. Geophys. Res., 109, B09401, https://doi.org/10.1029/2002JB002350, 2004.

Chevalier, M. L., Ryerson, F. J., Tapponnier, P., Finkel, R. C., Jermo, V. D. W., Li, H. B., and Liu, Q.: Slip-Rate measurements on the Karakorum fault may imply secular variations in fault Motion, Science, 307, 411-414, 2005.

China Earthquake Administration, GB/T 17742-2008: The Chinese seismic intensity scale, issued by the General Administration of Quality Supervision, Inspection and Quarantine of the People's Republic of China \& Standardization Administration of the People's Republic of China, 2008.

China Earthquake Administration: An intensity map of Tibet for the M 8.1 Nepal earthquake, available at: https://www.cea.gov.cn/ cea/dzpd/dzzt/369476/369477/1231101/index.html, last access: 1 May 2015.

Cui, P., Zhuang, J. Q., Chen, X. C., Zhang, J. Q., and Zhou, X. J.: Characteristics and countermeasures of debris flow in Wenchuan area after the earthquake, J. Sichuan Univ., (Engineer. Sci. Ed.), 42, 10-19, 2010.

Dadson, S. J., Hovius, N., Chen, H., Dade, W. B., Lin, J. C., Hsu, M. L., Lin, C. W., Horng, M. J., Chen, T. C., Milliman, J., and Stark, C. P.: Earthquake-triggered increase in sediment delivery from an active mountain belt, Geology, 32, 733-736, 2004.

Dellow, G. D. and Hancox, G. T.: The influence of rainfall on earthquake-induced landslides in New Zealand, in: Proceed. Tech. Groups, Earthqs. and Urban Develop: New Zealand Geotech. Soc. 2006 Sym., Nelson, New Zealand, 355-368, 2006.

Dewey, J., Shackleton, R. M., Chang, C., and Sun, Y.: The tectonic evolution of the Tibetan Plateau, Philos. T. R. S.-A, 327, 379413, 1988.

Elliott, J. R., Walters, R. J., England, P. C., Jackson, J. A., Li, Z., and Parsons, B.: Extension on the Tibetan plateau: recent normal faulting measured by InSAR and body wave seismology, Geophys. J. Int., 183, 503-535, https://doi.org/10.1111/j.1365246X.2010.04754.x, 2010.

Hovius, N., Meunier, P., Lin, C. W., Chen, H., Chen, Y. G., Dadson, S., Horng, M. J., and Lines, M.: Prolonged seismically induced erosion and the mass balance of a large earthquake, Earth Planet. Sc. Lett., 304, 347-355, https://doi.org/10.1016/j.eps1.2011.02.005, 2011.

Hungr, O., Leroueil, S., and Picarelli, L.: The Varnes classification of landslide types, an update, Landslides, 11, 167-194, https://doi.org/10.1007/s10346-013-0436-y, 2014.

Institute of Geophysics, China Earthq. Admin.: The M5.9 Tingri earthquake of April 252015 in Tibet, available at: http://www. cea-igp.ac.cn/tpxw/272116.shtml, last access: 10 May 2015.

IRIS: Special event: Nepal, Incorp. Research Insts for Seis, available at: http://ds.iris.edu/ds/nodes/dmc/specialevents/2015/ 04/25/nepal/, last access: 24 May 2015.

Jouanne, F., Mugnier, J. L., Pandey, M. R., Gamond, J. F., LeFort, P., Serrurier, L., Vigny, C., Avouac, J. P., and the Idylhim members: Oblique convergence in the Himalayas of western Nepal deduced from preliminary results of GPS measurements, Geophys. Res. Lett., 26, 1933-1936, 1999.

Larson, K., Burgmann, R., Bilham, R., and Freymueller, J. T.: Kinematics of the India-Eurasia collision zone from GPS measurements, J. Geophys. Res., 104, 1077-1093, 1999. 
Lavé, J. and Avouac, J. P.: Active folding of fluvial terraces across the Siwaliks Hills, Himalayas of central Nepal, J. Geophys. Res., 105, 5735-5770, 2000.

Li, G., Moelle, K. H. R., and Lewis, J. A.: Fatigue crack growth in brittle sandstones, Int. J. Rock. Mech. Min., 29, 469-477, 1992.

Massey, C. I., Della Pasqua, F., Taig, T., Lukovic, B., Ries, W., Heron, D., and Archibald, G.: Canterbury Earthquakes 2010/11Port Hills Slope Stability: Risk assessment for Redcliffs, GNS Sci., Wellington, New Zealand, p. 123, C Appendices, 2014a.

Massey, C. I., Taig, T., Della Pasqua, F., Lukovic, B., Ries, W., and Archibald, G.: Canterbury Earthquakes 2010/11 Port Hills Slope Stability: Debris avalanche risk assessment for Richmond Hill, GNS Sci. Consultancy Rept. 2014/34, 2014b.

Molnar, P. and Lyon-Caen, H.: Fault plane solutions of earthquakes and active tectonics of the Tibetan Plateau and its margins, Geophys. J. Int.., 99, 123-153, 1989.

Nara, Y., Morimoto, K., Yoneda, T., Hiroyoshi, N., and Kaneko K.: Effects of humidity and temperature on subcritical crack growth in sandstone, Int. J. Solids Struct., 48, 1130-1140, 2011.

Parker, R. N., Hancox, G. T., Petley, D. N., Massey, C. I., Densmore, A. L., and Rosser, N. J.: Spatial distributions of earthquakeinduced landslides and hillslope preconditioning in the northwest South Island, New Zealand, Earth Surf. Dynam., 3, 501-525, https://doi.org/10.5194/esurf-3-501-2015, 2015.

Petley, D. N., Dunning, S. A., and Rosser, N. J.: The analysis of global landslide risk through the creation of a database of worldwide landslide fatalities, in: Landslide Risk Management, edited by: Hungr, O., Fell, R., Couture, R., and Eberhardt, E., Balkema, the Netherlands, 2005.

Saba, S. B., van der Meijde, M., and van der Werff, H.: Spatiotemporal landslide detection for the 2005 Kashmir earthquake region, Geomorphology, 124, 17-25, https://doi.org/10.1016/j.geomorph.2010.07.026, 2010.

Tang, Ch., Li, W.-L., Ding, J., and Huang, X.: Field investigation and research on giant debris flow on august 14, 2010 in Yingxiu town, epicenter of Wenchuan earthquake, Earth Sci.-J. China Univ. Geosci., 36, 172-180, 2011.

The Science and Technology Committee and the archives in Xizang Autonomous Region: Tibet earthquakes, historical compilation, (v.1), People's Publishing House, Xizang, 1-583, 1982 (in Chinese).

USGS: Updated finite fault results for the Apr 25, $2015 \mathrm{Mw}$ $7.935 \mathrm{~km} \mathrm{E}$ of Lamjung, Nepal Earthquake (Version 1), U.S. Geol. Sur., Nat'l. Earthq. Info Center, available at: http://earthquake.usgs.gov/earthquakes/eventpage/us20002926\# scientific_finitefault, last access: 23 May 2015a.
USGS: Updated finite fault results for the May 12, $2015 \mathrm{Mw}$ $7.322 \mathrm{~km}$ SE of Zham, China Earthquake (Version 2), U.S. Geol. Sur. Nat'l Earthq. Info. Center, available at: http://earthquake.usgs.gov/earthquakes/eventpage/us20002ejl\# scientific_finitefault, last access: 23 May 2015b.

Varnes, D. J.: Slope movement types and processes, in: Landslides, analysis and control, edited by: Schuster, R. L., Krizek, R. J., special report 176: Transportation research board, National Academy of Sciences, Washington, DC, 11-33, 1978.

Wang, X. Y. and Han, Z. L.: Modeling of landslides hazards induced by the 2008 Wenchuan earthquake using ground motion parameters, in: Rock stress and earthquakes, edited by: Xie, F., Taylor \& Francis Group, London, 297-304, ISBN 978.0.415.60165.8, 2010.

Wu, Z. H., Barosh, P. J., Wu, Z. H., Hu, D. G., Zhan, X., and Ye, P. S.: Vast early Miocene lakes of the central Tibetan Plateau, Geol. Soc. Am. Bull., 120, 1326-1337, 2008.

Wu, Z. H., Ye, P. S., Barosh, P. J., and Wu, Z. H.: The October 6, 2008 Mw 6.3 magnitude Damxung earthquake, Yadong-Gulu rift, Tibet, and implications for present-day crustal deformation within Tibet, J. Asian Earth Sci., 40, 943-957, 2011.

Yang, W. T., Wang, M., Kerle, N., Van Westen, C. J., Liu, L. Y., and Shi, P. J.: Analysis of changes in post-seismic landslide distribution and its effect on building reconstruction, Nat. Hazards Earth Syst. Sci., 15, 817-825, https://doi.org/10.5194/nhess-15817-2015, 2015.

Yun, S.-H., Hudnut, K., Owen, S., Webb, F., Simons, M., Sacco, P., Gurrola, E., Manipon, G., Liang, C., Fielding, E., Milillo, P., Hua, H., and Coletta, A.: Rapid Damage Mapping for the 2015 Mw 7.8 Gorkha Earthquake Using Synthetic Aperture Radar Data from COSMO-SkyMed and ALOS-2 Satellites, Seismol. Res. Lett., 86, 1549-1556, https://doi.org/10.1785/0220150152, 2015.

Zekkos, D., Clark, M., Whitworth, M., Greenwood, W., West, A. J., Roback, K., Li, G., Chamlagain, D., Manousakis, J., Quackenbush, P., Medwedeff, W., and Lynch, J.: Observations of Landslides Caused by the April 2015 Gorkha, Nepal, Earthquake Based on Land, UAV, and Satellite Reconnaissance, Earthq. Spectra, 33, S95-S114, https://doi.org/10.1193/121616EQS237M, 2017.

Zhang, P. Z., Shen, Z. K., Wang, M., Gan, W. J., Burgmann, R., and Molnar, P.: Continuous deformation of the Tibetan Plateau from global positioning system data, Geology, 32, 809-812, 2004. 